\title{
ARTICLE
}

Received 14 Dec 2012 | Accepted 23 May 2013 | Published 18 Jun 2013 DOl: 10.1038/ncomms3052

\section{Exceptionally well-preserved Cretaceous microfossils reveal new biomineralization styles}

Jens E. Wendler ${ }^{1,2} \&$ Paul Bown ${ }^{3}$

Calcareous microplankton shells form the dominant components of ancient and modern pelagic sea-floor carbonates and are widely used in palaeoenvironmental reconstructions. The efficacy of these applications, however, is dependent upon minimal geochemical alteration during diagenesis, but these modifying processes are poorly understood. Here we report on new biomineralization architectures of previously unsuspected complexity in calcareous cell-wall coverings of extinct dinoflagellates (pithonellids) from a Tanzanian microfossil-lagerstätte. These Cretaceous 'calcispheres' have previously been considered biomineralogically unremarkable but our new observations show that the true nature of these tests has been masked by recrystallization. The pristine Tanzanian fossils are formed from fibre-like crystallites and show archeopyles and exquisitely constructed opercula, demonstrating the dinoflagellate affinity of pithonellids, which has long been uncertain. The interwoven fibre-like structures provide strength and flexibility enhancing the protective function of these tests. The low-density wall fabrics may represent specific adaptation for oceanic encystment life cycles, preventing the cells from rapid sinking.

\footnotetext{
${ }^{1}$ Department of Paleobiology, MRC-121, Smithsonian Institution, 10th and Constitution Ave, Washington DC 20560, USA. ${ }^{2}$ Department of Geosciences, Bremen University, PO Box 330440, 28334 Bremen, Germany. ${ }^{3}$ Department of Earth Sciences, University College London, Gower Street, London WC1E 6BT, UK. Correspondence and requests for materials should be addressed to J.E.W. (email: wendler@uni-bremen.de).
} 
C alcification is rare in eukaryotes but has arisen separately as a cell-wall covering in the coccolithophore, foraminifera and dinoflagellate marine protistan plankton groups ${ }^{1}$. These calcareous shells are widely used as environmental proxies and age-dating tools but despite these widespread geoscientific applications, their biomineralization is relatively poorly understood because it is difficult to maintain most living taxa in culture and their fossils are generally modified by diagenetic recrystallization of fine-scale primary structures. Calcareous shells of dinoflagellates are mostly spherical calcite tests $(\sim 10-180 \mu \mathrm{m})$ formed by the family Thoracosphaeraceae ${ }^{2}$ living in shelf and oceanic surface waters. Around 30 living species and 260 fossil species are known, with most extant forms producing calcareous immotile coccoid cells some of which function as reproductive resting cysts ${ }^{2,3}$. The simple fossil forms that have been included in the calcareous dinoflagellates have wall architectures with randomly-oblique, radial, tangential and inclined radial (pithonellid) crystallographic orientations ${ }^{4}$. Specimens of uncertain biological affinity, lacking diagnostic dinoflagellate characters, have been termed calcispheres or calcitarchs ${ }^{5}$ and include the extinct Cretaceous pithonellids. Here we show unsuspected ultrastructural complexity and morphological traits in pithonellid fossils, which have been previously unidentified due to the masking effects of diagenesis. These new structures shed light on the biological affinity of pithonellids and the biomineralogical functionality of their calcareous cell-wall coverings.

\section{Results}

The dominant Cretaceous calcispheres. The extinct pithonellid forms dominate late Cretaceous calcisphere assemblages and can occur in rock-forming abundance ${ }^{6-8}$. Before this study, their biomineralogically unremarkable architecture (Fig. 1a) and lack of unequivocal morphological features that characterize dinoflagellates (for example, tabulation and archeopyles) raised doubts concerning their true biological affiliation ${ }^{2,3,5}$. Most of these forms have appeared to be constructed from two single-layered walls of coarse $(>1 \mu \mathrm{m})$, equidimensional calcite crystallites, although specimens showing variable crystallite size and multiple wall layers have been observed infrequently and considered to represent ecophenotypic or intraspecific variability ${ }^{9,10}$

Our new observations come from material initially targeted for its preservation of unaltered foraminiferal calcite and used to generate high-quality geochemical palaeoclimate proxy records for the Palaeogene ${ }^{1,12}$. Geochemical evidence, but also the extraordinary preservation of coccolithophore calcareous microfossils ${ }^{13}$, have demonstrated the exceptional nature of the carbonate preservation in the Tanzanian sediments. Our new results come from Turonian $(89-93 \mathrm{Ma})^{14}$ sediments that are 30 million years older and extend this microfossil lagerstätte record into the Cretaceous.

Pithonellid ultrastructure. The Tanzanian pithonellid fossils are incomparably better preserved than any previously documented
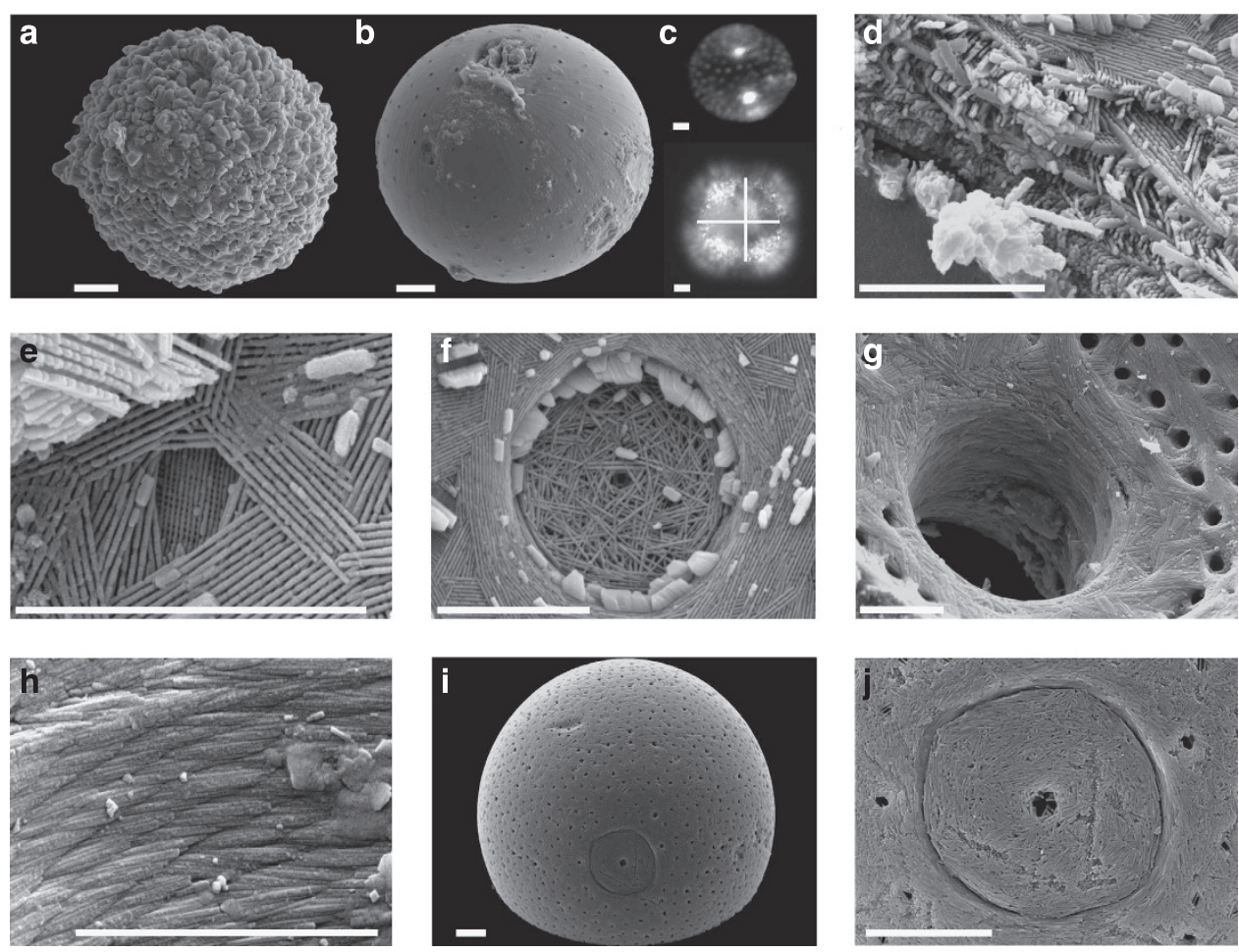

Figure 1 | New biomineralization styles in fossil pithonellids from Tanzanian Drill Site TDP 22. (a) Pithonella sp.; recrystallized cyst showing spiral rows of prismatic crystals masking primary surface traits. (b-f) Pithonella lamellata (60 specimens investigated); pristine cyst with smooth surface, an archeopyle, spiralling fine striations and perforations. (c) Optical imagery, reflected light (upper) and polarized light (lower). (d) Wall section showing ply-like multiple layers of submicron scale, fibre-like crystallites. (e) Inner cyst surface fabric and pore with sieve-like cover. (f) Inner cyst surface with operculum constructed of submicron, concentrically interwoven crystallites. (g,h) Bonetocardiella sp.; inner cyst surface with archeopyle, interwoven arrangement of the lamellar wall-crystallite patchwork and circular perforations. (h) Archeopyle wall showing rope-like interwoven crystallite bundles and winding architecture. (i,j) Pirumella multistrata (120 specimens investigated), a calcareous dinoflagellate cyst of the randomly-oblique wall architecture from TDP Site 22 for comparison; operculum constructed of randomly oblique, fibre-like crystallites. Scale bars, $5 \mu \mathrm{m}$. 
specimens ${ }^{15}$ yet they are assignable to known species based on their gross morphology and crystallographic orientation (Fig. 1b,c). Thus, we can show that the pristine pithonellid walls (Fig. 1d) are constructed from minute $(\sim 0.1 \mu \mathrm{m}$ wide), rod-like crystallites, often in groups of similar orientation (Fig. 1e-g), which are arranged in patchwork-like, partly interwoven patterns (Fig. 1f,h). These layers form a submicronscale lamination of the shell wall (Fig. 1d,h). Sub-angular, circular and slit-like perforations are typical and often outlined by concentrically arranged crystallites (Figs $1 \mathrm{~g}$ and $2 \mathrm{a}-\mathrm{c}, \mathrm{g}-\mathrm{i}$ ).

\section{Discussion}

These new observations suggest that most, if not all, previously described pithonellid-type microfossils have been strongly modified by recrystallization and bear little resemblance to their primary architectures. Importantly, we have observed large, taxonomically diagnostic circular to sub-angular openings (Fig. 1g) and corresponding plate-like coverings (Fig. 1f,i,j). These openings, called archeopyles, and their associated covering plates, called opercula, are characteristic of the immotile cells of dinoflagellates and are related to hatching (excystment) of new motile cells. The presence of distinct apical archeopyles is compelling evidence for the dinoflagellate affinity of the extinct Cretaceous microfossils shown here.

The dinoflagellate affinity of these fossils is also supported by the observation of interwoven submicron scale crystallite wall fabrics and the resulting laminated wall architecture, which is comparable to that seen in certain living dinoflagellates, particularly Leonella granifera (Fig. 2d-f). The characteristic interlocking of individual crystals that form the rod-like crystallites is seen in both L. granifera cysts (Fig. 2e) and pithonellids (Fig. 3a). Study of extant calcareous dinoflagellates has shown that biomineralization is initiated as crystal-like particles of calcite within cytoplasmic vacuoles, which then move to the cell periphery and deposit the crystals in a layer or matrix surrounding the cell ${ }^{16}$. The shell of the coccoid cells of Leonella has one matrix ${ }^{16}$ and shows no layering, whereas the multilayered construction of pithonellids suggests a complex matrix consisting of multiple organic layers.

The fine-crystalline interwoven and fibre-reinforced, perforate, laminated fabric of pithonellids (Fig. 3b) forms a shell construction that provides a balance of strength and flexibility, which is crucial for maximum resilience and thus protection of the cell. Similar woven fibre structures are also seen elsewhere in biominerals, such as, sea urchin tooth calcite ${ }^{17}$. In particular, near identical structure is seen in vertebrate dental enamel fabric (Fig. 3c), where it is largely responsible for the resilience of these structures, made of an otherwise inherently weak material ${ }^{18}$ yielding potential applications in biomimetics ${ }^{17}$. Furthermore, such low-density biocalcification is likely a specific adaptation for oceanic encystment life cycles, preventing the cysts from sinking below the photic zone to water depths from which they could not recover following excystment.

\section{Methods}

Material and field procedures. The studied specimens were recovered from a borehole drilled during the 2007 phase of the Tanzanian Drilling Project (TDP). Drill Site TDP 22 is situated at $10^{\circ} 04^{\prime} 39.4^{\prime \prime} \mathrm{S} / 39^{\circ} 37^{\prime} 33.5^{\prime \prime} \mathrm{E}$ and recovered lower through middle Turonian sediments (upper Whiteinella archaeocretacea and Helvetoglobotruncana helvetica planktic foraminiferal biozones) ${ }^{19}$. The sediments are siltstones with a carbonate content typically ranging from $10-15 \mathrm{wt} \%$. Samples were disaggregated in tap water at the drill site and size-fraction-separated over 20, 63,125 and $250 \mu \mathrm{m}$ sieves.
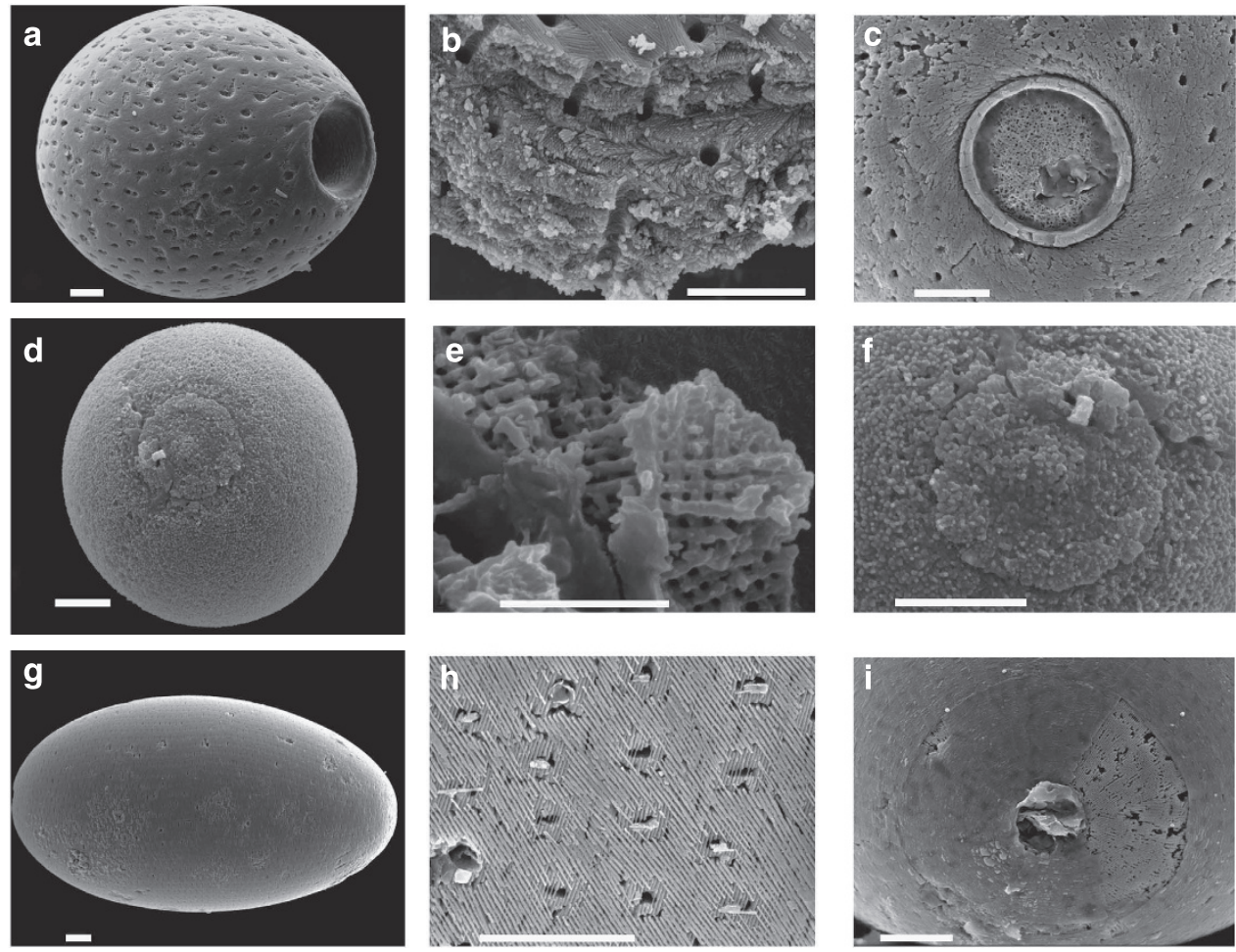

Figure 2 | Perforation types and comparison with extant calcareous dinoflagellates. (a-c) Bonetocardiella sp. from TDP Site 22 with sub-angular perforations. (b) Wall microfabrics in tangential, slightly oblique section. (c) Operculum. (d-f) Leonella granifera (extant species from culture, eight specimens studied) showing circular perforations. (e) Tangential section of wall microfabrics consisting of an array of interlocking individual crystals forming a laminated wall, scale bar $2 \mu \mathrm{m}$. (f) Operculum. (g-i) Pithonella ovalis (238 specimens studied), the type species of the genus Pithonella, from TDP Site 22. (h) Wall microfabrics of parallel fibre-like crystallites and slit-like perforations. (i) Operculum. Scale bars, $5 \mu \mathrm{m}$ (a-d and f-i). 

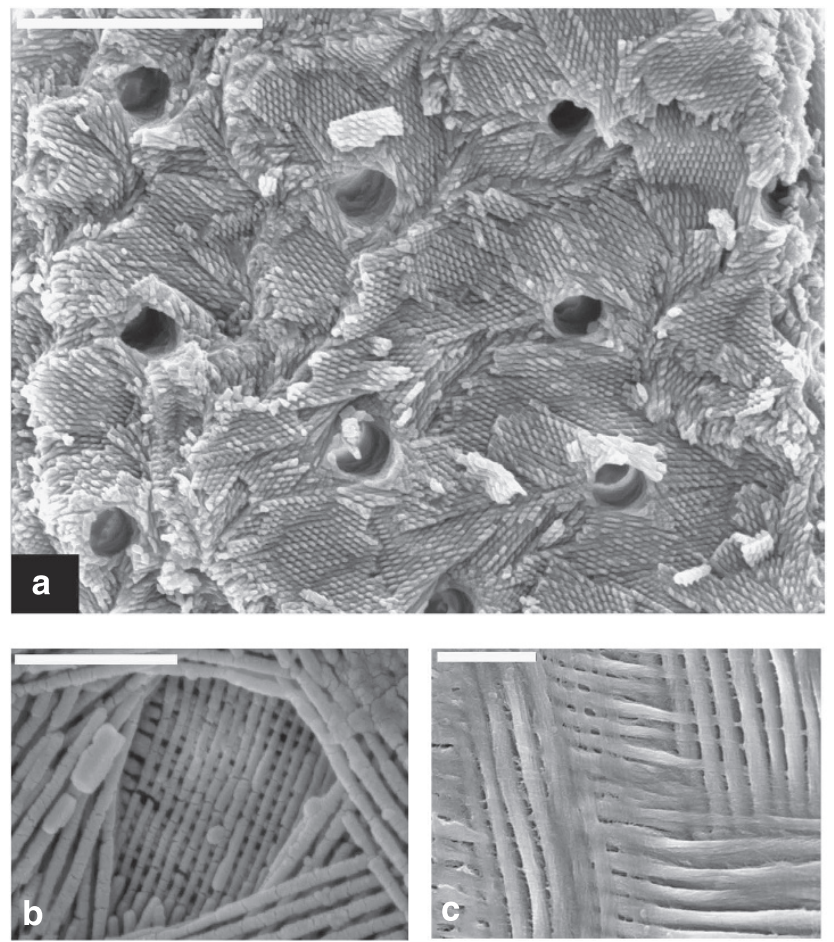

Figure 3 | Ultrastructure of the pithonellid biomineral architecture and comparison with vertebrate enamel. (a) Tangential, slightly oblique section of Bonetocardiella sp. (TDP Site 22) shows various planes of the wavy lamination (seen in cross-section in Fig. 1h) of the cyst wall. Note the interlocking of the individual calcite crystals resembling textile fabrics. Scale bar, $5 \mu \mathrm{m}$. (b) Pithonellid inner shell surface view showing the fibre-like and laminated fabric around an enlarged sieve-like perforation formed by orthogonal interlocked crystallites. Scale bar, $1 \mu \mathrm{m}$. (c) Cross-ply structure of densely interwoven fibres of rat enamel. Scale bar, $10 \mu \mathrm{m}$ (image reproduced courtesy of Dr Laurie B. Gower, http://gower.mse.ufl.edu/ research.html).

Analyses. Calcispheres were picked from the 20 - to $63-\mu \mathrm{m}$ size fraction $(5-10 \mathrm{mg}$ per sample) with an eyelash attached to a pen. Microscope magnification was ca. $\times 100$. Scanning electron microscopy was performed on a Phillips XL-30 ESEM with a LaB6 electron source. The microscopic analysis comprised four steps. First, the whole specimen was documented with reflected light-optical imaging using a Nikon SMZ1500 binocular light microscope and multiple-plane integrated imaging with NIS Elements imaging software. Second, transmitted polarized light-optical investigation facilitated identification of the crystallographic wall type using a Leitz Ortholox binocular microscope after transferring specimens onto a glass slide. An eccentric extinction cross (Fig. 1c) indicates an inclined radial (pithonellid) crystallographic orientation. Third, specimens were mounted on stubs for scanning electron microscopy imaging of the whole cysts and surface morphology and traits. Fourth, the specimens were opened, using a scalpel, to examine internal wall structure and inner surfaces of the cyst.

\section{References}

1. Knoll, A. H. in Biomineralization Vol. 54 (eds Dove, P. M., De Yoreo, J. J. \& Weiner, S.) Ch. 11, 381 (Mineralogical Society of America, 2003).

2. Elbrächter, M. et al. Establishing an Agenda for Calcareous Dinoflagellate Research (Thoracosphaeraceae, Dinophyceae) including a nomenclatural synopsis of generic names. Taxon 57, 1289-1303 (2008).

3. Streng, M., Hildebrand-Habel, T. \& Willems, H. A proposed classification of archeopyle types in calcareous dinoflagellate cysts. J. Paleontol. 78, 456-483 (2004).

4. Keupp, H. Die kalkigen Dinoflagellatenzysten des Mittelalb bis Untercenoman von Escalles/Boulonnais (N-Frankreich). Fazies 16, 6-21 (1987).
5. Versteegh, G. J. M., Servais, T., Streng, M., Munnecke, A. \& Vachard, D. A discussion and proposal concerning the use of the term calcispheres. Palaeontology 52, 343-348 (2009).

6. Wendler, J. E., Gräfe, K. U. \& Willems, H. Reconstruction of mid-Cenomanian orbitally forced palaeoenvironmental changes based on calcareous dinoflagellate cysts. Palaeogeogr. Palaeocl. 179, 19-41 (2002).

7. Dias-Brito, D. Global stratigraphy, palaeobiogeography and palaeoecology of Albian-Maastrichtian pithonellid calcispheres: impact on Tethys configuration. Cretaceous Res. 21, 315-349 (2000).

8. Wendler, J. E., Gräfe, K. U. \& Willems, H. Palaeoecology of calcareous dinoflagellate cysts in the mid-Cenomanian Boreal Realm: implications for the reconstruction of palaeoceanography of the NW European shelf sea. Cretaceous Res. 23, 213-229 (2002).

9. Kohring, R., Gottschling, M. \& Keupp, H. Examples for character traits and palaeoecological significance of calcareous dinoflagellates. Paläont. Z. 79, 79-91 (2005).

10. Keupp, H. \& Kienel, U. Wandstrukturen bei Pithonelloideae (Kalkige Dinoflagellaten-Zysten): Biomineralisation und systematische Konsequenzen. Abh. Geol. B.-A. 50, 197-217 (1994).

11. Pearson, P. N. et al. Warm tropical sea surface temperatures in the Late Cretaceous and Eocene epochs. Nature 413, 481-487 (2001).

12. Pearson, P. N., Foster, G. L. \& Wade, B. S. Atmospheric carbon dioxide through the Eocene/ Oligocene climate transition. Nature 461, 1110-1113 (2009).

13. Bown, P. R. et al. A Paleogene calcareous microfossil Konservat-Lagerstatte from the Kilwa Group of coastal Tanzania. Geol. Soc. Am. Bull. 120, 3-12 (2008).

14. Wendler, I., Huber, B. T., MacLeod, K. G. \& Wendler, J. E. Stable oxygen and carbon isotope systematics of exquisitly preserved Turonian foraminifera from Tanzania-understanding isotope signatures in fossils. Mar. Micropaleontol. doi: 10.1016/j.marmicro.2013.04.003.

15. Wendler, J. E., Wendler, I., Huber, B. T. \& Rose, T. Using cathodoluminescence spectroscopy of Cretaceous calcareous microfossils to distinguish biogenic from early-diagenetic calcite. Microsc. Microanal. 18, 1-9 (2012).

16. Zinssmeister, C., Keupp, H., Tischendorf, G., Kaulbars, F. \& Gottschling, M. Ultrastructure of Calcareous Dinophytes (Thoracosphaeraceae, Peridiniales) with a focus on vacuolar crystal-like particles. PLoS One 8, e54038 (2013).

17. Gower, L. B. Biomimetic model systems for investigating the amorphous precursor pathway and its role in biomineralization. Chem. Rev. 108, 4551-4627 (2008).

18. Chai, H., Lee, J. J.-W., Constantin, P. J., Lucas, P. W. B. R. \& Lawn, B. R. Remarkable resilience of teeth. Proc. Natl Acad. Sci. USA 106, 7289-7293 (2009).

19. Jiménez Berrocoso, Á. et al. Lithostratigraphy, biostratigraphy and chemostratigraphy of Upper Cretaceous sediments from southern Tanzania: Tanzania Drilling Project Sites 21 to 26. J. Afr. Earth Sci. 57, 47-69 (2010).

\section{Acknowledgements}

This research was supported by DFG fund WE 4587/1-1 (Wendler) and the Natural Environment Research Council (Bown). Ines Wendler, Sebastian Meier, Gerard Versteegh, Jeremy Young, Helmut Willems, Laurie Gower and Brian Huber are kindly thanked for conversations and comments on the manuscript. We thank Monika Kirsch for discussion on extant calcareous dinoflagellates and providing culture material. We acknowledge the Tanzania Petroleum Development Corporation, and particularly Dr Joyce Singano, for logistical support and the Tanzania Commission for Science and Technology for permission to drill.

\section{Author contributions}

J.E.W. carried out the palaeontological analyses, imaging, wrote the paper and created figures. P.B. was involved in fieldwork, project organization, palaeontological analyses, wrote the paper and discussed the results with J.E.W.

\section{Additional information}

Competing financial interests: The authors declare no competing financial interests.

Reprints and permission information is available online at http://npg.nature.com/ reprintsandpermissions/.

How to cite this article: Wendler, J. E. et al. Exceptionally well-preserved Cretaceous microfossils reveal new biomineralization styles. Nat. Commun. 4:2052 doi: 10.1038/ ncomms3052 (2013). 